\title{
The Strategic Flexibility of INTEREST RATE SWAPS
}

\author{
Russ Ray \\ School of Business \\ The University of Louisville \\ Louisville, Kentucky
}

The purpose of this article is to articulate a new and remarkably powerful financial tool which affords firms a previously unavailable degree of financial flexibility. Interest rate swaps-an exchange of interest-rate payments between two parties without an exchange of the underlying debt-were developed in the 1980 's and are already approaching $\$ 200$ billion in annual volume. Swap applications include: decreasing borrowing costs; increasing asset yields; altering asset and liability structures; changing borrowing indices; and managing basis risk. This article demonstrates these applications and thereby articulates the strategic and tactical flexibility effected by utilizing interest rate swaps.

\section{Arranging Swap Agreements}

Swap agreements are easily arranged by intermediaries-mostly commercial and investment bankers-who match up parties needing one or more of the services discussed below. Frequently, the intermediating bank will match up parties anonymously, so that the opposite parties to a swap agreement remain unknown to each other and deal only with the respective bank. Swap agreements are virtually risk-free, because if one party defaults on an interest-rate payment to a second party, the second party simply stops payment to the first party. If an intermediary bank is used (as is usually the case), the bank will only swap payments once both payments have been made. Thus, default risk is mechanically precluded.

Besides specifying the dollar amounts and due dates of the payment, the swap contract typically specifies the length of the agreement, the method and provisions for terminating the contract, and any other such information deemed pertinent to the execution of the contract. Swap agreements are legally binding agreements.

Although the swap market is usually a market for wholesale money (say, for transactions of $\$ 1$ million and up), some banks will intermediate for lesser amounts. A firm interested in swaps should contact its bank to determine the benefit/cost feasibility of using swaps. Typically, the intermediating bank will charge each party a fee of about $1 / 8$ to $1 / 5$ percent of the amount being

Journal of Business Strategies, Volume 5, Number 1 (Spring 1988) 
swapped, depending upon the dollar volume. As this market evolves, freemarket competition will probably reduce bank fees even further.

\section{Some Typical Swap Applications}

One of the most common applications of swaps is to lower a firm's borrowing rate. Typically, a smaller, less creditworthy firm enters into a swap agreement with a larger, more established firm, with the result being that both firms reduce their borrowing costs.

Consider two firms: an AAA-rated firm which can borrow short-term on a floating-rate basis at $7 \%$, and long-term on a fixed-rate basis at $9 \%$; and an A-rated firm which can borrow short-term (floating rate) at $8 \%$, and long-term (fixed rate) at $12 \%$. Suppose the AAA-rated firm needs short-term, floating rate funds, and the A-rated firm needs long-term, fixed-rate funds. Each firm can obtain its funds more cheaply by entering into an interest rate swap with the other firm. (See Figure 1)

Figure 1

How Interest Rate Swaps Lower Borrowing Costs

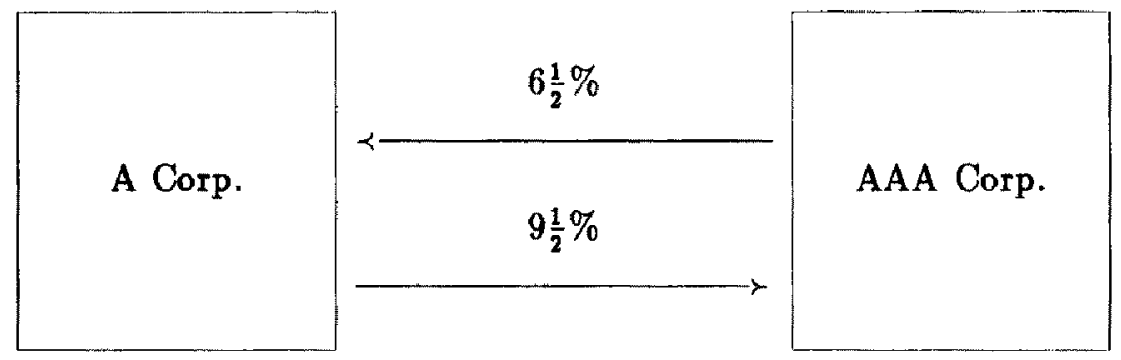

1. $\quad$ ST Borrowing Rate $=8 \% \quad$ 1. ST Borrowing Rate $=7 \%$

2. LT Borrowing Rate $=12 \%$ 2. LT Borrowing Rate $=9 \%$

3. Desires LT Funding

3. Desires ST Funding

AAA Corp's Cost of ST Funding $=6 \frac{1}{2} \%-\left(9 \frac{1}{2} \%-9 \%\right)=6 \%$

A Corp's Cost of LT Funding $=9 \frac{1}{2} \%+\left(8 \%-6 \frac{1}{2} \%\right)=11 \%$

The AAA-rated firm could borrow $\$ X$ long-term at $9 \%$, and the A-rated firm could borrow $\$ X$ short-term at $8 \%$. The two firms could then enter into a swap agreement whereby the AAA-rated firm agrees to pay $6 \frac{1}{2} \%$ to the A-rated firm on a short-term basis, and the A-rated firm agrees to pay $9 \frac{1}{2} \%$ to the AAA-rated firm on a long-term basis.

The result is that each firm obtained its desired type of funding more cheaply than it otherwise could have. The AAA-rated firm is effectively paying $6 \%$ for short-term, floating rate money $\left(6 \%=6 \frac{1}{2} \%-\frac{1}{2} \%\right)$; and the A-rated firm is effectively paying $11 \%$ for long-term, fixed rate money $\left(11 \%=9 \frac{1}{2} \%+1 \frac{1}{2} \%\right)$. Thus, before bank fees, each firm obtained its desired funding at 100 basis points 
less than it otherwise could have. After bank fees of $1 / 8$ to $1 / 5$ percent, each firm will obtain its funding at 80 to $87 \frac{1}{2}$ basis points less than otherwise would have been possible. For large sums of money, such a reduction in borrowing rates translates into significant savings.

This example also exemplifies another common application of interest rate swaps; transforming variable-rate loans into fixed-rate loans, and vice versa. If the hypothetical loans in the example above had already been on the books of the two firms, then a swap agreement would have effectively exchanged loans between the two firms. Notice that the AAA-rated firm effectively transformed its fixed-rate loan into a variable-rate loan, and the A-rated firm effectively transformed its variable-rate loan into a fixed-rate loan. The ability to quickly and easily transform loans from variable to fixed-rate (or vice versa) gives a firm a tremendous degree of flexibility and protection, especially during periods of volatile interest rates.

Instead of exchanging the interest payments on debt, these two firms could have just as easily exchanged the interest receipts on interest-bearing assets. The result of an income exchange is twofold: 1) to increase the yield or assets; and, 2) to change variable-rate assets into fixed-rate assets (or vice versa). Other applications of interest rate swaps include: unlocking high-coupon debt, changing borrowing indices, and closing balance-sheet gaps.

\section{The Principle of Comparative Advantage}

Interest rate swaps are nothing more than a modern-day application of the principle of comparative advantage, first derived by the economist David $\mathrm{Ri}$ cardo to explain international trade. In the example above, the AAA-rated firm has an absolute advantage of borrowing in both the short-term and the long-term markets, but it has a comparative advantage in the long-term market.

Therefore, it behooves both firms for the AAA-rated firm to borrow in the long-term market and the A-rated firm to borrow in the short-term market, and to thereafter trade interest payments. The spread differential of $2 \%$ (3\% longterm differential, less $1 \%$ short-term differential) represents the total savings resulting from an interest rate swap. In this example, the savings were divided evenly, although they could have been divided in any manner summing to $2 \%$.

In general, any time two firms have differing borrowing costs in the money and capital markets, both firms can economically benefit from an interest rate swap. The same holds true with respect to assets as long as a spread differential exists. The benefits accruing to two parties engaging in an interest rate swap are the domestic analogue of the benefits accruing to two countries engaged in international trade. 


\section{Conclusion}

Interest rate swaps are a new, innovative, and remarkably powerful financial tool, the market for which is growing rapidly. The technique affords firms a previously unavailable degree of flexibility in their financial planning and in their financially adapting to environmental circumstances. Because swaps are based upon the principle of comparative advantage, they will likely become a permanent financial practice, perhaps listed and traded on major exchanges.

\section{References}

1. Arnold, T. "How to Do Interest Rate Swaps." Harvard Business Review, Vol. 62 (September/October 1984), pp. 96-101.

2. Bicksler, J. and Chan, A. "An Economic Analysis of Interest Rate Swaps." Journal of Finance, Vol. 61 (July 1986), pp. 645-655.

3. Lereah, D. "The Growth of Interest Rate Swaps." Bankers Magazine, May/June 1986, pp. 36-41.

4. Walmsley, J. "Interest Rate Swaps: The Hinge Between Money and Capital Markets." The Banker, April 1985, pp. 37-40.

5. Walmsley, J. "Understanding Interest Rate Swaps." Bankers Magazine, July/August 1984, pp. 44-47.

6. Wishon, K. and Chevalier, L. "Interest Rate Swaps-Your Rate or Mine?" Journal of Accountancy, Vol. 63 (September 1985), pp. 63-84. 